\title{
Food Security, Safety, and Nutritional Concerns during a COVID-19 Pandemic: the Global Challenges
}

\author{
Irfan Khan ${ }^{1}$, Fahad Khan ${ }^{2 *}$ (i) , Pratibha Pandey ${ }^{2 \mathbb{D}}$, Abdul Haque ${ }^{3}$, Mohammad Mustufa Khan ${ }^{4}$ \\ 1 Department of Food Processing and Technology, Gautam Buddha University, Greater Noida, 201308, India, \\ khan.irfan380@gmail.com (I.K.); \\ 2 Department of Biotechnology, Noida Institute of Engineering and Technology, Greater Noida, 201306, India, \\ fahadkhan.bio@niet.co.in, (P.P.); \\ 3 Department of Post Harvest Engineering \& Technology, Aligarh Muslim University, Aligarh, Uttar Pradesh, 202002, \\ India, haqueamumech@gmail.com (A.H.); \\ 4 School of Biological Engineering \& Sciences, Shobhit University, Gangoh, Saharanpur (U.P.), 247 341, India, \\ mustufakhan01084@gmail.com (M.M.K.); \\ * Correspondence: fahadkhan.bio@niet.co.in; fahadintegralian@gmail.com (F.K.);
}

Scopus Author ID 57201049984

Received: 31.08.2020; Revised: 25.09.2020; Accepted: 28.09.2020; Published: 3.10.2020

\begin{abstract}
The world has already been suffering from the long-standing problems of food security, safety, and nutrition. The situation intensifies severely during the COVID-19 pandemic. Around 2 billion people had no daily access to healthy, nutritious, and sufficient food as per pre-COVID-19 statistics of food and drug administration. This number has been increased exponentially during this pandemic situation. The efforts are being made by the government and several non-government organizations (NGOs) for the distribution of food among the needy people at the national and international levels. In India, the public distribution system (PDS-system) plays a crucial role in achieving the targets for food security. Similar operations are carried out by various countries to fill needy people's bellies during this corona pandemic. Apart from food security, food safety and nutritional security are the primary concerns that must be addressed to ensure proper nutrition and safety for the consumers. In India, people mostly purchase the food items from the mobile vendors moving around, mandis, and/or nearby markets where the fruits, vegetables, and other food items are sold in an open environment. This market culture is responsible for thousands of death due to foodborne illness annually. It is worst in India and other developing countries that foods are sold in the open while shoes in a controlled environment. So, there may be risks and hazards associated with the food items available in the market that may increase the severity of primary infection with the nCOVID. Therefore, precautionary measures should be taken by food employers and consumers to meet sanitation and hygiene requirements. People should also follow the food and nutrition guidelines have been released by WHO and other statutory organizations to rejuvenate and strengthen the immune system during the quarantine period. Although, in the world, a great deal of effort is being made. However, there is a significant lack, especially in underdeveloped and developing countries, of such resources and facilities that could have been used to raise awareness and save lives in this pandemic COVID-19 and future.
\end{abstract}

Keywords: COVID-19;garlic; onion; 6 LU7;molecular docking.

(C) 2020 by the authors. This article is an open-access article distributed under the terms and conditions of the Creative Commons Attribution (CC BY) license (https://creativecommons.org/licenses/by/4.0/).

\section{Introduction}

The novel coronavirus is a life-threatening pandemic outbreak taken in Wuhan city of China at the beginning of December 2019, now spread around the whole world except few countries such as North Korea, Tajikistan, Turkmenistan, and South African countries [1]. The 
novel coronavirus has been declared a public health emergency of international concern on 29th Jan 2019 by world health organizations. The novel COVID-19 is a single-stranded RNA (26 - $32 \mathrm{~kb})$ virus belongs to genus Betacoronovirus, subgenus Sarbecovirus, family Coronaviridae and found closely related ( $88 \%$ identical) to SARS-like coronaviruses derived from bat $[2,3]$. The outbreak has disturbed the normal cycle of human life, especially the food value chain, which is one of the most concerning issues that created food and nutritional security throughout the world. The novel coronavirus spread from the droplets of infected person expels through sneezing, coughing, and sometimes through speaking \& breathing [4,5]. It is important to note that COVID-19 does not spread through food. During this pandemic situation, millions of people have lost their jobs due to the closing of industries, academic institutions, etc. Now, it is a challenge for every country to fill the belly of its citizens. Many countries have proving food and monetary benefits to their citizens. The food security concerns should give priority over the nutritional security during this pandemic period. It is the government's responsibility to ensure the food security issues for its citizens at this point of pandemic lockdown in India and the world as well. The pandemic situation of the novel coronavirus in India disturbed the value chain of food and agriculture, which left people in limited or no food at their end. In this crucial time, where no permanent cure or treatment is available, prevention is the best way to save people's lives. The WHO and relevant Indian authorities have issued several preventive guidelines, such as wearing face-masks, washing hands with sanitizer periodically, and essentially maintaining social distancing.

The FDA and WHO issued the businesses' food safety guidelines to avoid any kind of spread risk of the novel coronavirus. In India, similar guidelines have been issued by FSSAI (Food Safety Standard Authority of India) for food businesses to prevent any kind of spread risk of the novel coronavirus [6]. Simultaneously, such food safety guidelines have not been circulated in the public domain at the end of consumers effectively due to India's lack of awareness. Therefore, each person has to advise their contacts about hygiene and food protection guidelines when buying the fruit, vegetables, and local street vendors. Similar care must be taken in the buying and storage of food items. It has been found in the investigation that the novel coronavirus can survive up to 4 hours on the copper surface, 24 hours on cardboard, and 72 hours on the surface of plastics and stainless steel [7].

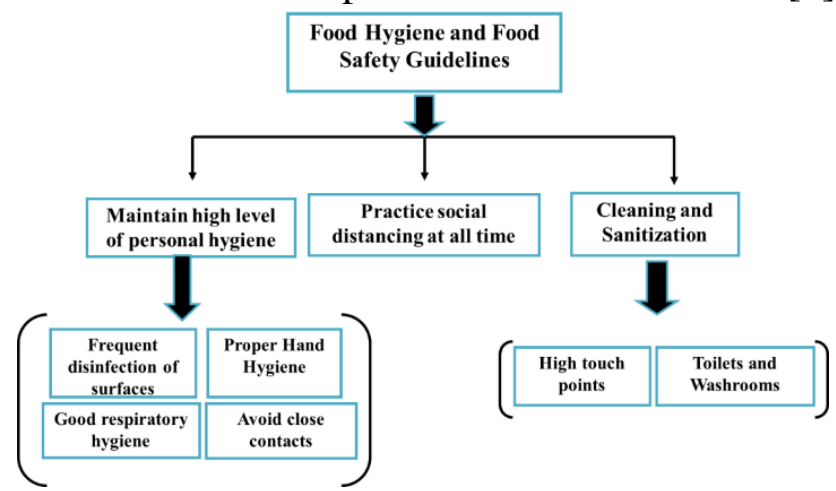

Figure 1. Food hygiene and food safety guidelines.

So, the processed foods packaged in metallic packaging may be responsible for spreading the disease. Although, the government authorities are creating awareness among the peoples with their best of efforts. In our opinion, the government should handover these responsibilities to all government and non-government organizations and the concerned people to create awareness regarding food safety and hygiene near or around their vicinity. The FSSAI circulated the guidelines about healthy\& nutritious foods, particularly for those who have home 
quarantines and at the risk of COVID-19. Although the International statutory organizations have issued the guidelines for food and nutrition for self quarantined and risky people. The food safety standard authority of India released the guidelines regarding food hygiene \& safety for food businesses [8]. The FSSAI describes the guidelines for food businesses, i.e., food employees, food handlers, etc. Three major safety guidelines were released, as shown in figure 1.

\section{Food security issues}

Around 820 million people are facing chronic hunger. This is the category of peoples not getting sufficient food to provide minimum caloric value for their lives. Around 113 million of these face acute severe insecurity and have to depend upon external sources for assistance to survive [9]. The present pandemic situation will enlarge the list beyond 820 million throughout the world and simultaneously created a life-threatening psychological, social insecurity among the daily wagers such as laborers in rural and urban areas. This pandemic situation is more difficult for Africa's vulnerable communities, already grappling with hunger problems [9]. The developing countries are comparatively facing more serious problems than the developed nations, such as India, Afghanistan, Pakistan, Bangladesh, Sri Lanka, and the other countries, which directly or indirectly depend upon these countries for various resources. This paper will discuss more in the context of India regarding food security issues. India has the largest number of undernourished people in the world viz., approximately 195 million. Nearly 47 million people do not meet their minimum nutrition demands and suffer from chronic undernutrition health problems [10]. In India, poor people are so much in fear that hunger may kill them before coronavirus. Due to a lack of proper infrastructure and good policies, The Indian government cannot disseminate its services as per demand. It is practically quite cumbersome to fill these pits without having sophisticated food marketing models. India is the second-largest producer of fruits and vegetables after China. This indicates no deficiency of any food commodity in India; even then, people are fighting for their livelihoods. This is a significant concern in the present and the future as well. There is a great need to reinvent the public distribution system and make it more efficient and transparent at the end of India (Figure 2).

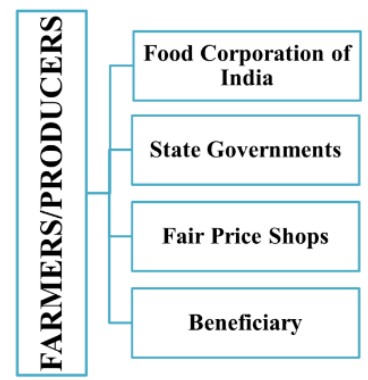

Figure 2. Route of the public distribution system in India.

\section{Community kitchen model in India during the COVID-19 pandemic}

India has started the community kitchens in all its states and territories to feed the poor people during the lockdown due to the COVID-19 pandemic. The efforts being made to address and assure the food security problems for poor people. The state governments are running these community kitchens and feeding millions of people daily. Recently, Uttar Pradesh (India) became the first state to geotag their community kitchens so that the needy people could get 
their geographical locations easily through Google search. The U.P. government has geotagged their 7,368 community kitchens and community shelters across 75 districts of Uttar Pradesh [11]. The U.P. community kitchens produce 12 lakhs food packets daily and serve its responsibility in a better way during this pandemic situation [12]. On the other hand, Kerala state community kitchens distributing around 2.5 to 2.8 lakhs of food packets daily, as shown in figure 3 [13]. A similar community kitchen model is running throughout the country in India. This is our opinion that after this pandemic situation, the efforts should be continued as millions of people sleep without getting food daily in India. Along with government bodies, the nongovernment organizations also playing a crucial role in providing the food to the needy people in different states in India. One of the most famous international NGOs involved in food distribution is Khalsa Aid in India and abroad. Several other communities are arranging Langer programs to distribute the food at local levels.

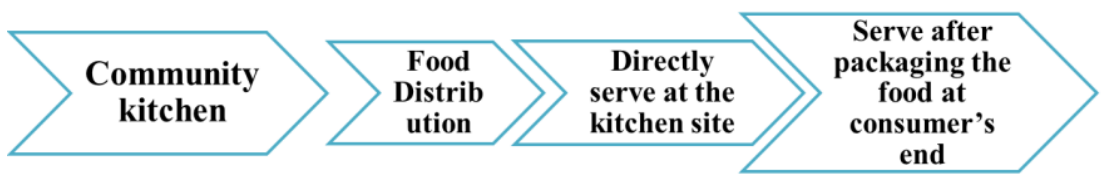

Figure 3. Community kitchen model in India [13].

\section{Food safety guidelines for consumers}

Thousands of people have been died throughout the world due to the novel coronavirus outbreak. The spread potential of COVID-19 is much more effective than other variants of this virus, such as the SARS virus. That's why creating awareness about COVID-19 pathogenicity is very important as a preventive measure. The coronavirus transmits through person to person contact and through fomites and respiratory droplets generated during the coughing and sneezing of an infected person [14-20]. The transmission of COVID-19 through food or food packaging is not found yet. However, safety and hygiene precautions should not be ignored while handling food items. To strengthen the food safety regulations throughout the world, the food and drug administration (FDA), United States, published the Food code model [21] that will help control food jurisdictions at different levels. The FDA Food code model must essentially be implemented along with national regulatory policies. In Indian, markets are not well organized and sophisticated. There is a huge share of the Indian market that constitutes the unorganized sector. In India, the consumers purchase food items such as packaged food products directly from the grocery stores and the fruits and vegetables from the local street vendors, mandis, etc. The sanitization and hygiene level is very poor among the whole market in Indian. So, the precaution must be taken at the consumer's level to check the spread risk of COVID-19 through food items. The novel coronavirus may spread indirectly by touching the groceries and shopping bags. The following guidelines have been suggested to use for consumers [22]. It is suggested that the food employers provide single-use carrier bags for food commodities to check the cross-contamination, if any. Unfortunately, if the packaging material got the virus at their surfaces, they may spread the virus to the individuals; As the outer layer of the novel coronavirus is made up of fat/lipid, so it is recommended to use alcohol-based hand sanitizer for consumers. This is because alcohol kills the novel coronavirus by solubilizing the outer lipid layer of the virus. The formulation of sanitizer must work as per the WHO standard; The raw fruits and vegetables should rinse with the running tap water before removing any dust particles, pathogenic microbes, including the COVID-19 virus, to reduce the spread risk in the individuals. 


\section{Food and nutrition guidelines for consumers}

There is no proper medical solution available for the treatment of novel coronavirus affected patients to date. Many countries are putting their efforts to make vaccines against COVID-19, and some of them have started testing on primates other than humans. The final result is yet to come. In this scenario, the preventive measures are the only ways to check and reduce the risk of novel coronavirus among the community. Proper food and nutrition guidelines should be followed by the individuals, particularly those quarantined at home, to boost their immunity against any kind of infection risk. It can be improved with a healthy diet plan and take foods rich in protein, fiber, antioxidants, vitamins, minerals, and other components. The office for Prevention and Control of Non communicable diseases Europe, WHO has developed the food and nutritional guidelines that should be followed by the consumers during self-quarantine [23] (Figure 4).

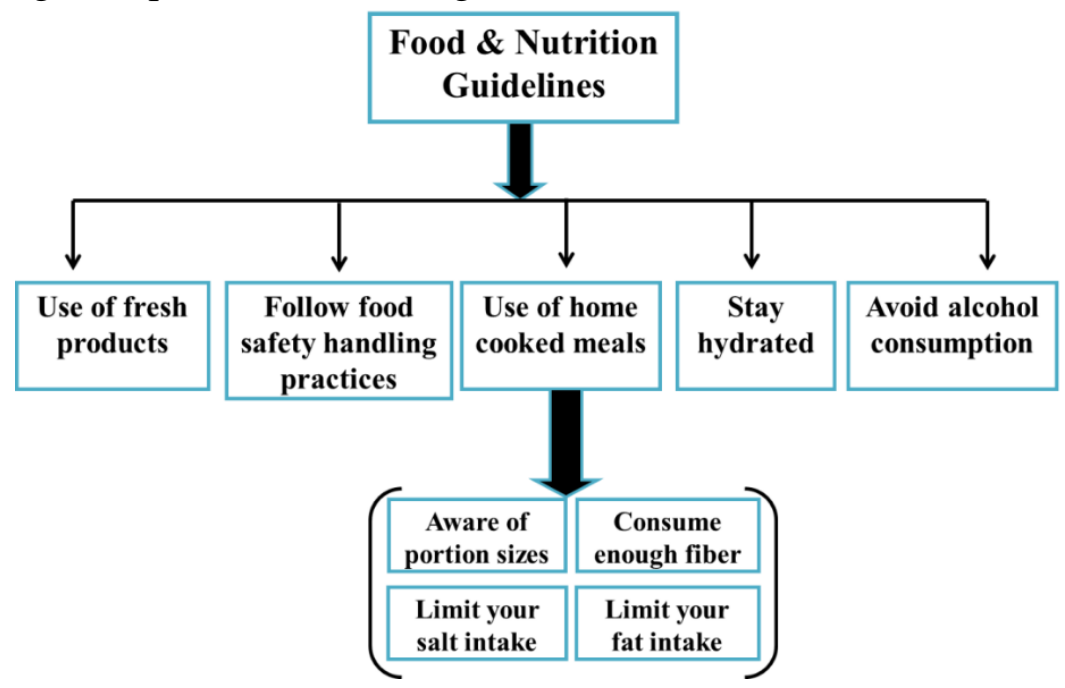

Figure 4. Food safety and nutrition guidelines.

In a healthy meal plate, one quarter should be vegetables, a second-quarter from whole grains. The other two quarters would then comprise high protein foods such as meat, fish, eggs, legumes, and healthy dairy products in three equal portions [24]. It is also recommended to make a meal with olive oil and consume plenty of water [24].

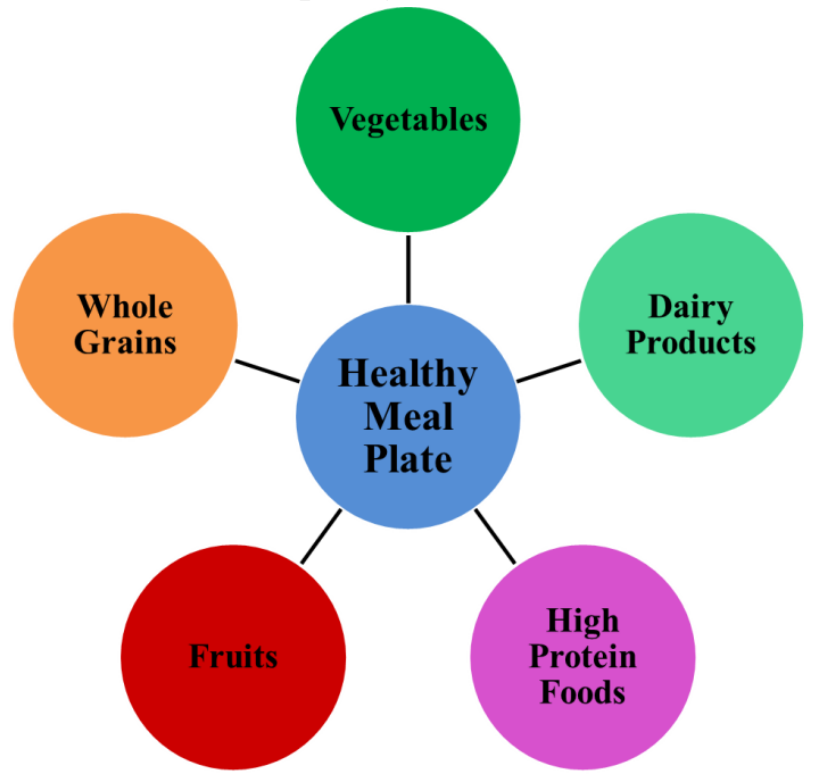

Figure 5. Healthy eating plan during the quarantine period. 


\section{Nutrition therapy during the quarantine}

The problems of abdominal pain and diarrhea were recorded in some coronavirus patients during treatment that might be due to antiviral/anti-infective drugs or the infection of intestinal mucosa [25]. It was found that the balance of microflora in the intestine of patients disturbed, which let the patients at a high risk of secondary infections. So, it is necessary to maintain a balance of intestinal microflora by supplementing a diet rich in probiotics. As people are staying at homes due to the corona pandemic and consuming large quantities of fat, carbohydrate, and protein, which could lead to psychological problems such as boredom [26]. The dietary guidelines are most important in the patients already suffering from cardiovascular diseases, diabetes, hypertension, lung diseases, etc. These patients are at more risk of severe complications of novel coronavirus [27]. That's why parallel nutrition therapy helps treat infected people.

\section{Conclusions}

The government at the national level of every country should fix and guarantee health and nutrient quality concerns and food security problems. So that the poor will then get food to satisfy their lowest calorie needs. Various attempts at the national level are being made as an indigenous community kitchen model, and millions of people benefit. The best way of managing COVID-19 spread is by taking prevention steps in the absence of adequate treatment, e.g., drug, vaccination, etc. To strengthen or enhance individual immunity against COVID-19, among the many preventive steps, food safety and the diet guidelines are critical. No corona case was observed, and no empirical research has yet come to this effect from fruits, vegetables, and other foodstuffs. However, the safest remedy is always prevention. Why should anybody gamble it? Consumers should follow the required hygiene and sanitation recommendations when buying raw foodstuffs to prevent any harm. Finally, customers and businessmen should obey the food safety recommendations issued by foreign and domestic law enforcement agencies, such as WHO, FDA, FAO, and FSSAI (India), to mitigate the chances of infections with COVID 19.

\section{Funding}

This research received no external funding.

\section{Acknowledgments}

The authors are thankful to the Department of Post Harvest Engineering and Technology, Aligarh Muslim University to provide a cordial and healthy academic environment. No funding was received for this work.

\section{Conflicts of Interest}

The authors declare no conflict of interest.

\section{References}

1. Ren, L.-L.; Wang, Y.-M.; Wu, Z.-Q.; Xiang, Z.-C.; Guo, L.; Xu, T.; Jiang, Y.-Z.; Xiong, Y.; Li, Y.-J.; Li, X.-W.; Li, H.; Fan, G.-H.; Gu, X.-Y.; Xiao, Y.; Gao, H.; Xu, J.-Y.; Yang, F.; Wang, X.-M.; Wu, C.; Chen, L.; Liu, Y.-W.; Liu, B.; Yang, J.; Wang, X.-R.; Dong, J.; Li, L.; Huang, C.-L.; Zhao, J.-P.; Hu, Y.; Cheng, Z.-S.; Liu, L.-L.; Qian, Z.-H.; Qin, C.; Jin, Q.; Cao, B.; Wang, J.-W. Identification of a novel coronavirus 
causing severe pneumonia in human: a descriptive study. Chinese Medical Journal 2020, 133, https://doi.org/10.1097/CM9.0000000000000722.

2. Lu, R.; Zhao, X.; Li, J.; Niu, P.; Yang, B.; Wu, H.; Wang, W.; Song, H.; Huang, B.; Zhu, N.; Bi, Y.; Ma, X.; Zhan, F.; Wang, L.; Hu, T.; Zhou, H.; Hu, Z.; Zhou, W.; Zhao, L.; Chen, J.; Meng, Y.; Wang, J.; Lin, Y.; Yuan, J.; Xie, Z.; Ma, J.; Liu, W.J.; Wang, D.; Xu, W.; Holmes, E.C.; Gao, G.F.; Wu, G.; Chen, W.; Shi, W.; Tan, W. Genomic characterisation and epidemiology of 2019 novel coronavirus: implications for virus origins and receptor binding. The Lancet 2020, 395, 565-574, https://doi.org/10.1016/s0140-6736(20)302518.

3. Khot, W.; Nadkar, M. The 2019 Novel Coronavirus Outbreak - A Global Threat. The Journal of the Association of Physicians of India 2020, 68, 67-71.

4. Cohen, E. 2020. "Experts Tell White House Coronavirus Can Spread Through Talking or Even Just Breathing." CNN Health, April 4. https://edition.cnn.com/2020/04/02/health/aerosol-coronavirus-spreadwhitehouseletter/index.html.

5. Lanese, N. COVID-19 May Spread Through Breathing and Talking_but We Don't Know How Much. Live Science April $7 \mathbf{2 0 2 0 .}$

6. Gopalan, H.S.; Misra, A. COVID-19 pandemic and challenges for socio-economic issues, healthcare and National Health Programs in India. Diabetes \& Metabolic Syndrome: Clinical Research \& Reviews 2020, 14, 757-759, https://doi.org/10.1016/j.dsx.2020.05.041.

7. van Doremalen, N.; Bushmaker, T.; Morris, D.H.; Holbrook, M.G.; Gamble, A.; Williamson, B.N.; Tamin, A.; Harcourt, J.L.; Thornburg, N.J.; Gerber, S.I.; Lloyd-Smith, J.O.; de Wit, E.; Munster, V.J. Aerosol and Surface Stability of SARS-CoV-2 as Compared with SARS-CoV-1. New England Journal of Medicine 2020, 382, 1564-1567, https://doi.org/10.1056/NEJMc2004973.

8. Food safety standard authority of India. Food safety guidelines for businessmen and buyers. 2020.

9. Food and Agriculture Organizations. FAO reports on Food security and livelihoods during the corona pandemic. 2020. http://www.fao.org/2019-ncov/q-and-a/impact-on-food-and-agriculture/en/.

10. Food and Agriculture Organizations. FAO reports on The State of Food Security and Nutrition in the World. 2019. https://www.wfp.org/publications/2019-state-food-security-and-nutrition-world-sofi-safeguardingagainst-economic

11. Rao, P.A.; Malik, P.; Prabhath, M.; Nayar, K.R. COVID-19 Containment: Lessons From Bengaluru and Mumbai Cities in India. SSRN 2020, http://dx.doi.org/10.2139/ssrn.3661046.

12. Bhagat, R.; Sahoo, H.; Archana, S.; Roy, K.; Govil, D. The COVID-19, Migration and Livelihood in India A Background Paper for Policy Makers International Institute for Population Sciences, Mumbai The COVID-19, Migration and Livelihood in India. 2020.

13. Kerala Govt. Community kitchens dish out 2.8 lakh food packets a day in Kerala. 2020. Www.inventina.co.in.

14. Liu, J.; Liao, X.; Qian, S.; Yuan, J.; Wang, F.; Liu, Y.; Wang, Z.; Wang, F.S.; Liu, L.; Zhang, Z. Community Transmission of Severe Acute Respiratory Syndrome Coronavirus 2, Shenzhen, China, 2020. Emerg Infect Dis 2020, 26, 1320-1323, https://doi.org/10.3201/eid2606.200239.

15. Chan, J.F.-W.; Yuan, S.; Kok, K.-H.; To, K.K.-W.; Chu, H.; Yang, J.; Xing, F.; Liu, J.; Yip, C.C.-Y.; Poon, R.W.-S.; Tsoi, H.-W.; Lo, S.K.-F.; Chan, K.-H.; Poon, V.K.-M.; Chan, W.-M.; Ip, J.D.; Cai, J.-P.; Cheng, V.C.-C.; Chen, H.; Hui, C.K.-M.; Yuen, K.-Y. A familial cluster of pneumonia associated with the 2019 novel coronavirus indicating person-to-person transmission: a study of a family cluster. The Lancet $\mathbf{2 0 2 0}$, 395, 514-523, https://doi.org/10.1016/S0140-6736(20)30154-9.

16. Li, Q.; Guan, X.; Wu, P.; Wang, X.; Zhou, L.; Tong, Y.; Ren, R.; Leung, K.S.M.; Lau, E.H.Y.; Wong, J.Y.; Xing, X.; Xiang, N.; Wu, Y.; Li, C.; Chen, Q.; Li, D.; Liu, T.; Zhao, J.; Liu, M.; Tu, W.; Chen, C.; Jin, L.; Yang, R.; Wang, Q.; Zhou, S.; Wang, R.; Liu, H.; Luo, Y.; Liu, Y.; Shao, G.; Li, H.; Tao, Z.; Yang, Y.; Deng, Z.; Liu, B.; Ma, Z.; Zhang, Y.; Shi, G.; Lam, T.T.Y.; Wu, J.T.; Gao, G.F.; Cowling, B.J.; Yang, B.; Leung, G.M.; Feng, Z. Early Transmission Dynamics in Wuhan, China, of Novel Coronavirus-Infected Pneumonia. New England Journal of Medicine 2020, 382, 1199-1207, https://doi.org/10.1056/NEJMoa2001316.

17. Huang, C.; Wang, Y.; Li, X.; Ren, L.; Zhao, J.; Hu, Y.; Zhang, L.; Fan, G.; Xu, J.; Gu, X.; Cheng, Z.; Yu, T.; Xia, J.; Wei, Y.; Wu, W.; Xie, X.; Yin, W.; Li, H.; Liu, M.; Xiao, Y.; Gao, H.; Guo, L.; Xie, J.; Wang, G.; Jiang, R.; Gao, Z.; Jin, Q.; Wang, J.; Cao, B. Clinical features of patients infected with 2019 novel coronavirus in Wuhan, China. The Lancet 2020, 395, 497-506, https://doi.org/10.1016/S01406736(20)30183-5.

18. Burke, R.M.; Midgley, C.M.; Dratch, A.; Fenstersheib, M.; Haupt, T.; Holshue, M.; Ghinai, I.; Jarashow, M.C.; Lo, J.; McPherson, T.D.; Rudman, S.; Scott, S.; Hall, A.J.; Fry, A.M.; Rolfes, M.A. Active Monitoring of Persons Exposed to Patients with Confirmed COVID-19 - United States, January-February 2020. MMWR. Morbidity and mortality weekly report 2020, 69, 245-246, http://dx.doi.org/10.15585/mmwr.mm6909e1.

19. World Health Organization.Report of the WHO-China Joint Mission on Coronavirus Disease 2019 (COVID19) 16-24 February 2020 [Internet]. Geneva: World Health Organization; 2020.

20. Ong, S.W.X.; Tan, Y.K.; Chia, P.Y.; Lee, T.H.; Ng, O.T.; Wong, M.S.Y.; Marimuthu, K. Air, Surface Environmental, and Personal Protective Equipment Contamination by Severe Acute Respiratory Syndrome 
Coronavirus 2 (SARS-CoV-2) From a Symptomatic Patient. JAMA 2020, 323, 1610-1612, https://doi.org/10.1001/jama.2020.3227.

21. Food and Drug Administration. FDA reports on the Food code model. 2019. www.fda.gov

22. World Health Organization. COVID-19 and food fafety: guidance for food businesses: interim guidance, 07 April 2020. World Health Organization. 2020.

23. World health organization (2020b). WHO/Prevention and Control of Noncommunicable diseases report. WHO, Europe office; 2020.

24. Turkey Dietary Guidelines. Ankara: Ministry of Turkey Health Publication. 2016.

25. Liang, T. Handbook of COVID-19 prevention and treatment. The First Affiliated Hospital, Zhejiang University School of Medicine. Compiled According to Clinical Experience $\mathbf{2 0 2 0 .}$

26. Moynihan, A.B.; Tilburg, W.A.P.v.; Igou, E.R.; Wisman, A.; Donnelly, A.E.; Mulcaire, J.B. Eaten up by boredom: consuming food to escape awareness of the bored self. Frontiers in psychology 2015, 6, https://doi.org/10.3389/fpsyg.2015.00369.

27. Wu, C.; Chen, X.; Cai, Y.; Xia, J.a.; Zhou, X.; Xu, S.; Huang, H.; Zhang, L.; Zhou, X.; Du, C.; Zhang, Y.; Song, J.; Wang, S.; Chao, Y.; Yang, Z.; Xu, J.; Zhou, X.; Chen, D.; Xiong, W.; Xu, L.; Zhou, F.; Jiang, J.; Bai, C.; Zheng, J.; Song, Y. Risk Factors Associated With Acute Respiratory Distress Syndrome and Death in Patients With Coronavirus Disease 2019 Pneumonia in Wuhan, China. JAMA Internal Medicine 2020, 180, 934-943, https://doi.org/10.1001/jamainternmed.2020.0994. 